\title{
An Exploration of Interesting Clauses in Sports
}

\author{
ADAM EPSTEIN \\ Central Michigan University
}

\section{INTRODUCTION}

The purpose of this article is to explore a broad spectrum of some of the more prominent and interesting contract clauses that have worked their way into the practice of law in the business of sport. The study of these clauses can provide students with an opportunity to appreciate the legal issues and contracts from both an historical and practical perspective. Many of the examples utilized in this article reflect the fundamental principles of contract law generally. This article is also designed to offer the law professor pedagogical insights and queries when appropriate.

The relevant sports law provisions and clauses in this article are found in individual employment and sponsorship contracts, league constitutions, tournament rules, and in the collective bargaining agreements between owners and the players in the big four sports leagues. ${ }^{1}$ Contract clauses have played a significant role in the sports industry and sports law at amateur, recreational, intercollegiate and professional levels. Thus, exploration of these clauses extends beyond a fundamental study of the efficacy of utilizing an exculpatory clause commonly found in road races and other outdoor activities such as

1. The big four is a phrase commonly used to describe the four major North American professional sports leagues: the National Basketball Association (NBA), the National Football League (NFL), Major League Baseball (MLB) and the National Hockey League (NHL). See, e.g., Marc Edelman, How to Curb Professional Sports' Bargaining Power Vis-à-vis the American City, 2 VA. SPORTS \& ENT. L.J. 280, 291 (2003); see also Tim Chapin, Sports Facilities and Development: The Political Economy of Sports Facility Location: An End-of-the-Century Review and Assessment, 10 MARQ. SPORTS L.J. 361 (2000). 
adventure sports. ${ }^{2}$ It also extends beyond an examination of typical incentive or bonus clauses in standard player or endorsement contracts. ${ }^{3}$

Analyzing contract clauses in sports requires an understanding and appreciation of the interrelationship between judicial decisions among different jurisdictions, the evolving role of professional league commissioners, and the impact and history of law in general in the United States. Thus, the study and analysis of clauses in sports contracts provides an opportunity for students to study American history and the evolution of legal precedent as well. Whether due to the infiltration of unions into major league sports, the changing view of civil rights in the 1960s, or the impact over the financial influx into sports as a direct result of the influence of television or the ubiquitous Internet, professors and students alike can consider how and why the following clauses have been utilized to reflect the meeting of the minds and the principle that contractual agreements must be respected and enforced. ${ }^{4}$

\section{THE RESERVE CLAUSE}

One of the first clauses that any student, professor or practitioner should acknowledge in the study of sports and the law is the now outdated reserve clause which was found in baseball in all standard player contracts starting in the late $1880 \mathrm{~s}^{5}{ }^{5}$ Under the professional baseball reserve system in place for decades, players were required to sign contracts that bound them to their teams permanently if they wanted to remain in the sport. ${ }^{6}$ That is, the club retained their rights even at the expiration of the contract unless the player was traded or released at the team's option alone. In essence, this reduced players' bargaining power to next to nothing. ${ }^{7}$ This system was designed, of course, to restrict salaries and it gave owners greater leverage during contract

2. See Beth A. Easter, Sarah E. Hardin \& Tammie L. Stenger, Legal Issues Related to Adventure Racing, 13 J. LEGAL ASPECTS OF SPORT 253, 258-9 (2003).

3. See, e.g., Associated Press, Asomugha Misses Incentives; Raiders Void 3-year, \$45.3M Deal, SPORTS ILLUSTRATED, Jan. 9, 2011, available at http://sportsillustrated.cnn.com/ 2011/football/nfl/01/09/asomugha.raiders.ap/index.html (noting clause in the contract specifically granting team the option to void the largest contract for a defensive back in professional football history if certain incentives were not reached).

4. Nike Int'l, Ltd. v. Athletic Sales, Inc., 689 F. Supp. 1235, 1245 (D.P.R. 1988) (translating the contract law doctrine pacta sunt servanda as "agreements must be respected"); see also generally Richard Hyland, Pacta Sunt Servanda: A Meditation, 34 VA. J. INT'L L. 405 (1994).

5. See Ryan T. Dryer, Beyond The Box Score: A Look at Collective Bargaining Agreements in Professional Sports and Their Effect on Competition, 2008 J. DISP. RESOL. 267, 268 (2008).

6. Id. (noting that if the player refused to sign the new contract, he was left with two options: (1) continue to play for the current team, or (2) permanently retire from baseball).

7. $I d$. 
negotiations. In fact, with the advent of the amateur baseball draft in 1965, players lost even more leverage than they might have already had since, prior to that time, at least if they did not want to play for a team they could refuse to sign a contract at all and no team held their rights. Occasionally a rival league would appear, increasing players' bargaining power, but such occurrence was only temporary. ${ }^{8}$

The Major League Baseball (MLB) reserve clause was found in Paragraph 10 (a) of the Uniform Player's Contract, and stated, in part,

...If prior to the March 1 next succeeding said December 20, the Player and the Club have not agreed upon the terms of such contract, then on or before 10 days after said March 1, the Club shall have the right by written notice to the Player at said address to renew this contract for the period of one year on the same terms,...?

Oddly, it took decades for there to be a successful challenge to the ambiguity in the clause found in Paragraph 10 (a). The team owners' perspective was that the clause, "to renew this contract for the period of one year on the same terms" gave them the right to annually renew a player's contract and could be used perpetually in order to keep a player under contract. However, Marvin Miller, a former economist for the United Steelworkers of America turned executive director of the Major League Baseball Players Association (MLBPA) asserted that another reasonable interpretation of Paragraph 10 (a) might be that of a one-shot deal, giving a team the ability to renew a player's contract for only one year not to be built on top of a previous Paragraph 10 (a) extension. ${ }^{10}$ As leader of the players union, he was able to get the owners to agree to its first collective bargaining agreement in 1968 part of which provided a procedure to handle grievances, a prelude for a formal challenge to this reserve clause by MLB pitcher Curt Flood. $^{11}$

8. See Mitchell Nathanson, The Irrelevance of Baseball's Antitrust Exemption: A Historical Review, 58 RUTGERS L. REV. 1, 12 (2005) (recognizing that a legal challenge was brought by the Federal League against Major League Baseball clubs).

9. See Adam Primm, Salary Arbitration Induced Settlement in Major League Baseball: The New Trend, 17 SPORTS LAW. J. 73, 115 (2010) (referencing the reserve clause in Andy Messersmith's reserve clause in the 1973-75 collective bargaining agreement).

10. See Martin M. Tomlinson, The Commissioner's New Clothes: The Myth of Major League Baseball's Antitrust Exemption, 20 ST. THOMAS L. REV. 255, 257 (2008).

11. See Ed Edmonds, At the Brink of Free Agency: Creating the Foundation for the MessersmithMcNally Decision 1968-1975, 34 S. ILL. U. L. J. 565, 618-19 (2010). 


\section{A. Federal Baseball}

Professional baseball has held (and continues to hold) a unique exemption from antitrust laws in accordance with the controversial interpretation by the Supreme Court in Federal Baseball Club of Baltimore, Inc. v. National League of Professional Baseball Clubs. ${ }^{12}$ The Baltimore Terrapins sued the team owners of the American and National Leagues, and the upstart Federal League, claiming that they all violated the federal Sherman Antitrust Act and that there was a conspiracy to monopolize professional baseball by destroying the Federal League which had been trying to compete with them.

Ultimately, the Supreme Court held that antitrust laws do not apply to professional baseball as the game of baseball did not affect interstate commerce. ${ }^{14}$ Even though teams and players traveled across state lines, Justice Oliver Wendell Holmes, for a unanimous court, wrote that such activity was only incidental to the game and that baseball was a form of entertainment. ${ }^{15}$ This judicial decision has caused considerable discussion, criticism and debate for almost 100 years. $^{16}$ Baseball has remained exempt from the federal antitrust laws since it did not affect interstate commerce. ${ }^{17}$ Thus, the Supreme Court legitimized the reserve clause with the Federal Baseball ruling, and the reserve clause did not constitute an antitrust violation even after several protracted yet unsuccessful legal challenges in subsequent years. ${ }^{18}$ This

12. Federal Baseball Club of Baltimore, Inc. v. National League of Prof'1 Baseball Clubs, 259 U.S. 200, 208 (1922) (asserting that baseball did not involve interstate commerce and, instead, "The business is giving exhibitions of base ball (sic), which are purely state affairs."); see also State v. Milwaukee Braves, Inc. 144 N.W.2d 1 (Wis. 1966) (holding that state laws antitrust laws were not applicable to the sport of baseball).

13. See Nathaniel Grow, Defining the "Business of Baseball": A Proposed Framework for Determining the Scope of Professional Baseball's Antitrust Exemption, 44 U.C. DAvIS L. REV. 557, 566-68 (2010) (noting that Baltimore won in district court, but that decision was overturned on appeal).

14. Federal Baseball Club of Baltimore, Inc., 259 U.S. at 209.

15. Id.

16. See, e.g., Jonathan D. Gillerman, Calling Their Shots: Miffed Minor Leaguers, the Steroid Scandal, and Examining the Use of Section 1 of the Sherman Act to Hold MLB Accountable, 73 ALB. L. REV. 541, 565-570 (2010).

17. $I d$.

18. Id. at 566; see Toolson v. New York Yankees, 346 U.S. 356 (1953) (noting that Congress did not intend it to include baseball when the Sherman Act was enacted in 1980); see also U.S. v. International Boxing Club of New York, 348 U.S. 236 (1955) (denial of antitrust exemption to professional boxing); Gardella v. Chandler, 172 F.2d 402, 408-09 (2d Cir. 1949) (discussing violation of reserve clause by player who commenced employment in the Mexican League); see also Craig $\mathrm{F}$. Arcella, Major League Baseball's Disempowered Commissioner: Judicial Ramifications of the 1994 Restructuring, 97 COLUM. L. REv. 2420, 2440-1 (1997). Though ultimately settled out of court, Danny Gardella successfully demonstrated MLB violated antitrust laws and that he was blacklisted by 
included the challenge by George Toolson, a minor league pitcher who remained at the AAA level in the New York Yankees' organization. ${ }^{19}$

\section{B. Curt Flood}

After the Great Depression, two World Wars, and decades of ineffective legal challenges to the reserve system, Curt Flood filed a lawsuit against MLB and the legitimacy of the reserve clause which ultimately proved to be the beginning of the end of the clause in MLB and similar systems in the other big four leagues. ${ }^{20}$ The all-star outfielder played for the St. Louis Cardinals but refused to accept a trade to the Philadelphia Phillies in 1969. Flood sued MLB and Commissioner Bowie Kuhn in order to become a free agent. ${ }^{21} \mathrm{He}$ argued that the reserve clause, inter alia, was an unreasonable restraint of trade under the Sherman Antitrust Act. ${ }^{22}$ Flood sat out the 1970 season and was traded to the Washington Senators the next year. ${ }^{23}$ His career ended when he retired after playing only 13 games for the Senators in $1971 .^{24}$

Still, Flood's case weaved its way through the legal system, and in 1972 the Supreme Court in a 5-3 decision acknowledged that MLB's antitrust exemption found in the Federal Baseball decision was an "anomaly," but it insisted that it was up to Congress to change this antitrust exemption. ${ }^{25}$ The decision led baseball owners to agree to an arbitration system which resulted following the Seitz arbitration decision in December 1975, in which MLB players Andy Messersmith and Dave McNally filed grievances through the MLBPA and successfully challenged the legitimacy of the reserve clause. ${ }^{26}$

MLB and Albert B. Chandler, its Commissioner, due to his breach of a contract with New York Giants in order to play professional baseball in Mexico.

19. Toolson, 346 U.S. 356 . In a 7-2 decision, the Supreme Court reaffirmed the Federal Baseball decision with a mere one-paragraph majority opinion.

20. Flood v. Kuhn, 407 U.S. 258 (1972); see also Grow, supra note 13, at 573-74 (noting that Flood also alleged a violation of the Thirteenth Amendment).

21. Grow, supra note 13 , at 574

22. Flood, 407 U.S. at 289.

23. See Farid Rushdi, The Washington Senators Played a Part in Baseball's Free Agent History, BLEACHER REPORT (Oct. 23, 2009), http://bleacherreport.com/articles/277211-the-washingtonsenators-played-a-part-in-baseballs-free-agent-history.

24. $I d$.

25. Flood, 407 U.S. at 282; see also Roger I. Abrams, Blackmun's List, 6 VA. SPORTS \& ENT. L.J. 181, 185 (2007) (noting that Justice Lewis Powell recused himself apparently due to his interest in Anheuser-Busch, the company that owned the St. Louis Cardinals).

26. Edmonds, supra note 11 , at 565. 
Curt Flood fought a good fight and set the stage for the Seitz decision, but his own legal challenge did not prevail. ${ }^{27}$

Curt Flood passed away on January 20, 1997 at age 59. ${ }^{28}$ Though he lost his legal battle, his persistent refusal to accept the status quo resulted in major changes to the professional sports landscape in other leagues as well, and the new four-year collective bargaining agreement between the owners and the players in MLB defined the parameters of a new era: free agency starting in 1976.29 Flood's landmark legal battle over the legitimacy of the reserve clause continues to have an impact on the American professional sports landscape. The Curt Flood Act of 1998 was, at least, an attempt by Congress to legislatively override the antitrust ruling in Federal Baseball. ${ }^{30}$ However, this Act only has limited effect because of the contemporaneous Supreme Court ruling in Brown v. Pro Football, Inc., in 1996. ${ }^{31}$ Signed into law by President Clinton, the Curt Flood Act of 1998 gave MLB players, like their counterparts in other leagues, the right to sue the league under antitrust laws provided they first decertify as a union. ${ }^{32}$ It is a generally held belief that the Curt Flood Act of 1998 is not the landmark law that some had hoped for. ${ }^{33}$

\section{Other Leagues}

Other than professional baseball, sports and leagues do not share the same antitrust exemption. ${ }^{34}$ Still, they too had their own share of legal claims alleging violations of the federal antitrust laws having utilized similar reserve clauses for many years. In Radovich v. National Football League, the Supreme Court declared that professional football, unlike professional baseball, was

27. Flood, 407 U.S. at 285 ("And what the Court said in Federal Baseball in 1922 and what it said in Toolson in 1953, we say again here in 1972: the remedy, if any is indicated, is for congressional, and not judicial, action.").

28. Rushdi, supra note 23.

29. See Philip R. Bautista, Congress Says, "Yooou're Out!!!" to the Antitrust Exemption of Professional Baseball: A Discussion of the Current State of Player-Owner Collective Bargaining and the Impact of the Curt Flood Act of 1998, 15 OHIO ST. J. ON DISP. RESOL. 445, 458 (2000).

30. Id. at 472; see also Curt Flood Act of 1998, 15 U.S.C. $\$ 26$ b (2011).

31. Brown v. Pro-Football, Inc., 518 U.S. 231 (1996) (holding that unionized employees cannot file antitrust suits individually when a union is there to represent their interests).

32. See generally Joshua P. Jones, A Congressional Swing and Miss: The Curt Flood Act, Player Control, and the National Pastime, 33 GA. L. REV. 639 (1999).

33. Id.; see also generally Lacie L. Kaiser, Revisiting the Impact of the Curt Flood Act of 1998 on the Bargaining Relationship between Players and Management in Major League Baseball, 2 DEPAUL J. SPORTS L. CONTEMP. PROBS. 230 (2004).

34. See, e.g., International Boxing Club v. U.S., 358 U.S. 242 (1955) (refusing to extend baseball's exemption to the sport of boxing). 
indeed subject to federal antitrust laws. ${ }^{35}$ The National Football League (NFL) later utilized the "Rozelle Rule" which allowed the league Commissioner Alvin Ray "Pete" Rozelle to compensate any NFL team that lost a free agent to another team. ${ }^{36}$ This compensation could include players, future draft picks and financial reimbursement. ${ }^{37}$ Most teams did not want to (or claimed not to want) lose draft picks or pay compensation so this rule held veteran players essentially hostage. ${ }^{38}$ Courts eventually found this plan to be an antitrust violation, and free agency appeared in professional football. ${ }^{39}$

In the National Hockey League (NHL), a reserve clause was the basis for the NHL's injunction against the large number of players who had signed with the rival World Hockey Association (WHA) in 1972. While the reserve clause was not explicitly struck down, a court in a case involving all-star Bobby Hull effectively blocked any further injunctions based on the reserve clause, making it unenforceable though the WHA eventually went out of business. ${ }^{40}$ Meanwhile, around the same time, the National Basketball Association (NBA) had its share of antitrust battles which led to a settlement agreement with Oscar Robertson (the lead plaintiff) ending the reserve system in that league as

35. Radovich v. National Football League, 352 U.S. 445 (1957) (holding that antitrust exemption is limited to baseball); see also Scott E. Backman, NFL Players Fight for Their Freedom: The History of Free Agency in the NFL, 9 SPORTS LAW. J. 1, 8 (2002). Radovich, an undrafted player from the University of Southern California signed with the Detroit Lions in 1938. After the end of World War II, he asked to be traded, but the Lions owner refused to comply. Radovich signed with a rival league and played for two season with the Los Angeles Dons but alleged he was blacklisted him for leaving the National Football League to go to the All-America Football Conference. He sued under the Clayton Act and alleged that he was a victim of a group boycott and he eventually settled the case out of court.

36. See Mackey v. NFL, 543 F.2d 606 (8th Cir. 1976) (holding that "Rozelle Rule" which restricted player movement between teams was an unreasonable restraint of trade in violation of section 1 of the Sherman Act).

37. Id. at 609 .

38. Id. at 622 .

39. See United States Football League v. National Football League, 842 F.2d 1335 (2d Cir. 1988) (upholding jury finding that the NFL had violated section 2 of the Sherman Act by attempting to prevent the USFL from competing in the market for major league professional football. However, the court affirmed the jury finding that the NFL did not have the power to prevent the USFL from obtaining a network television contract, as well as a jury verdict of $\$ 1$ in damages); see also Clarett $\mathrm{v}$. Nat'1 Football League, 306 F. Supp. 2 d 379 (S.D.N.Y. 2004), rev'd, 369 F.3d 124 (2d Cir. 2004), cert. denied, 125 S.Ct. 1728 (2005) (NFL minimum age rule was not an antitrust violation); but see Richard A. Kaplan, The NBA Luxury Tax Model: A Misguided Regulatory Regime, 104 Colum. L. REV. 1615, 1621-22 (2004) (noting that the NFL has a "franchise tag" now which, somewhat similar to the old reserve system, which can only be used once per season and, inter alia, requires teams to make an offer equal to the average of the top five salaries in the player's position).

40. See generally Philadelphia World Hockey Club, Inc., v. Philadelphia Hockey Club, Inc., 351 F. Supp. 457 (E.D. Pa. 1972). 
well. ${ }^{41}$ Thus, beginning with Curt Flood's challenge, other players' associations in professional football, hockey and basketball continued the contemporaneous momentum and rode the wave to fight to eliminate their respective reserve clauses during the early 1970 s and won.

An exploration of the reserve clause and its history in MLB and the other big four leagues allows professors and students to visit sports history and from a jurisprudential angle. It brings to life past eras, judicial decisions and allows an appreciation for the development of and comparison to today's free agent systems in the various sports. Most students today were not alive during the non-free agent eras of the past and a world without free agency is a foreign concept for most of them. A discussion of the reserve clause should provide today's students, especially Millenials, a solid historical foundation in the study of sports and the law. ${ }^{42}$

\section{III. "BEST INTERESTS" OF BASEBALL CLAUSE}

Interestingly, the reserve clause was not the only language that had been the forefront of discussion involving MLB. One specific power found in the MLB Constitution (MLC) involves a clause known as the "best interests of baseball" clause. ${ }^{43}$ Baseball's first Commissioner, Judge Kenesaw Mountain Landis, reluctantly took the job and only on the condition that he be given broad powers to discipline players in the "best interest of the game." ${ }^{44}$ The

41. See Robertson v. National Basketball Ass'n, 389 F. Supp. 867, 894 (S.D.N.Y. 1975) (referring to Philadelphia World Hockey Chub, Inc., 351 F. Supp. 462, in which "Judge Higgenbotham concluded that, as a matter of law, either a perpetual reserve system or one limited to three years' duration violates Section 2 of the Sherman Act as an unlawful monopolization."); see also Haywood v. Nat'l Basketball Ass'n, 401 U.S. 1204 (1971) (noting that professional basketball does not enjoy an exemption from antitrust laws); Denver Rockets v. All-Pro Mgmt., Inc., $325 \mathrm{~F}$. Supp. 1049 (C.D. Cal. 1971); Wood v. National Basketball Ass'n, 809 F.2d 954 (2d Cir. 1987) (holding that the non-statutory labor agreement barred an antitrust challenge to the NBA's salary cap and college draft since terms were specifically addressed in the collective bargaining agreement); Bridgeman v. Nat'l Basketball Ass'n, 675 F. Supp. 960 (D.N.J. 1987) (noting that once impasse is reached, an employer may unilaterally implement changes that are reasonably comprehended within the pre-impasse proposals); NBA v. Williams, 45 F.3d 684 ( $2 \mathrm{~d}$ Cir. 1995) (offering that the draft and salary cap were protected by the non-statutory labor exemption and unilateral implementation was acceptable post-impasse as long as in good faith).

42. See Joan Catherine Bohl, Generations $X$ and $Y$ in Law School: Practical Strategies for Teaching the "MTV/Google" Generation, 54 LOY. L. REV. 775, 778 (2008).

43. MAJOR LEAGUE CONSTITUTION ("MLC") (2005), available at http:/bizofbaseball.com/docs/ MLConsititutionJune2005Update.pdf.

44. See Matthew A. Foote, Three Strikes and You're (Not Necessarily) Out: How Baseball's Erratic Approach to Conduct Violations is not in the Best Interest of the Game, 6 DEPAUL J. SPORTS L. CONTEMP. PROBS 1,6 (2009). 
expression "best interests" is found nine times in the MLC. ${ }^{45}$ It starts in Article II, THE COMMISSIONER, Section 2 (b) which states that the functions of the Commissioner shall include the right to ". . .investigate, either upon complaint or upon the Commissioner's own initiative, any act, transaction or practice charged, alleged or suspected to be not in the best interests of the national game of Baseball. . ",46

Usually the Commissioners have used the best interests clause to protect the game's public image including on and off-the-field conduct.47 MLB Commissioners have also invoked the clause throughout the years to do various punitive things including handing down permanent player suspensions as part of the infamous 1919 Chicago White Sox bribery scandal among others. ${ }^{48}$

However, MLB Commissioner powers are not dictatorial. In 1994, as the acting Commissioner, Allen "Bud" Selig wrote a commentary in the New York Times newspaper in which he declared that the best interests powers were inherently narrow and created to ensure the integrity of the game and not meant to be all powerful. ${ }^{49} \mathrm{He}$ said, "[t]he notion of an almighty Commissioner directing the business of baseball is incorrect." ${ }^{, 0}$ In the case of player LaMarr Hoyt, the use of the best interest of baseball clause was curtailed when an arbitrator overruled Commissioner Peter Ueberroth who had suspended Hoyt for one year and, instead, reduced the punishment to sixty days. ${ }^{51}$ Hoyt had crossed the Mexican border with controlled substances and the San Diego Padres sought to terminate his contract accordingly. ${ }^{52}$

45. MLC, supra note 43 .

46. Id. Sec. 2 (c) then subsequently grants the Commissioner the ability, "To determine, after investigation, what preventive, remedial or punitive action is appropriate in the premises, and to take such action either against Major League Clubs or individuals, as the case may be.").

47. Foote, supra note 44, at 21-23 (discussing the concerns involving MLB player Steve Howe and how Commissioner Fay Vincent, after several attempts to give Howe second chances, decided that the first lifetime ban for drug use in baseball history would be implemented. However, this decision was challenged by the MLBPA, and arbitrator George Nicolau sided with Howe on the condition that he be tested every other day for the rest of his career).

48. Id. at $10-15$.

49. See Richard Sandomir, Selig Widens 'Best Interests' View in Rangers Bid, N.Y.TIMES (May 14, 2010), available at http:/www.nytimes.com/2010/05/15/sports/15sandomir.html.

50. Id.

51. Foote, supra note 44 , at 19.

52. Id. 
In recent years, however, Selig's interpretation of best interests has largely evolved and expanded. ${ }^{53}$ For example, Selig used the best interests clause in an ownership transition in 2001 when MLB purchased the Montreal Expos as part of a complicated series of deals involving three teams. ${ }^{54}$ Interestingly, in 2010, some suggested that Selig missed an opportunity to invoke the best interests of baseball clause to override an erroneous call made by MLB firstbase umpire Jim Joyce which forfeited the chance for Detroit Tigers pitcher Armando Galarraga to become only the $21^{\text {st }}$ pitcher in MLB history to pitch a perfect game. $^{55}$

MLB brought to the forefront of national discussion and legal debate two clauses in particular: the reserve clause of the outdated reserve system and the best interests of baseball clause which has been applied in various ways through the years by many MLB Commissioners. However, many other clauses have raised legal issues for players, coaches, agents, unions, and lawyers in the context of sport. Many of these clauses are found in individual contracts with teams, universities, endorsement contracts or the respective league collective bargaining agreements. These clauses provide a practical opportunity for students at any level to explore, compare and contrast statutory provisions, potential ambiguity concerns and might even be used as the basis for a drafting exercise as part of a class project as to how or when to incorporate such clauses.

\section{HAZARDOUS ACTIVITIES CLAUSES}

Teams in all the big four leagues certainly want to protect their investments in their multi- millionaire players. If the players are injured while participating in a risky activity outside the scope of their game, such injuries can impact everyone: players, owners, coaches, teammates, and fans. One of the contractual ways to attempt to mitigate the chances of an injury has been to utilize what are known as hazardous activity clauses. In essence, the clause allows the team, at its option, to modify the financial obligation to a player if a player is involved in a particular type of activity outside the context of their

53. Sandomir, supra note 49 (referencing the intermeddling by Selig in external matters of the game itself, as opposed to merely internal league rules violations, such as in the process involving the potential sale of the Texas Rangers to new owners in 2010).

54. See Zach Lowe, The Texas Rangers Sale: A Test Case for the Power of Sports Leagues?, THE AM. LAWYER (May 12, 2010), available at http:/www.law.com/jsp/tal/ PubArticleTAL.jsp?id=1202458105113\&The_Texas_Rangers_Sale_A_Test_Case_for_the_Power_of Sports Leagues\&hbxlogin=1. (noting that MLB eventually moved the Expos to Washington).

55. See Ian O'Connor, Hey Bud, Don't Shrug This One Off, ESPN (June 3, 2010), $\mathrm{http} / /$ sports.espn.go.com/new-york/mlb/columns/story?columnist=oconnor ian\&id $=5245642$. 
sport and is injured as a direct result. Hazardous activity clauses have been in the spotlight much more today than ever before and appear to be designed to be both deterrent and punitive in nature.

For example, Paragraph 12 ("Prohibited Activities") of the NBA's Uniform Player Contract prohibits a player from engaging in many things including "any activity that a reasonable person would recognize as involving or exposing the participant to a substantial risk of bodily injury," including "driving or riding a motorcycle or moped." $"$ Meanwhile, there is not a specific mention in the NHL's standard player contract that prohibits riding a motorcycle, although $\uparrow 7$ of its Standard Player's Contract provides:

The Player and the Club recognize and agree that the Player's participation in other sports may impair or destroy his ability and skill as a hockey player. Accordingly the Player agrees that he will not during the period of this Contract or during any period when he is obligated under this Contract to enter into a further contract with the Club engage or participate in football, baseball, softball, hockey, lacrosse, boxing, wrestling or other athletic sport without the written consent of the Club, which consent will not be unreasonably withheld. ${ }^{57}$

56. National Basketball Association, Collective Bargaining Agreement (July 2005). The NBA Uniform Player Contract, $\$ 12$, reads, in its entirety,

The Player and the Team acknowledge and agree that the Player's participation in certain other activities may impair or destroy his ability and skill as a basketball player, and the Player's participation in any game or exhibition of basketball other than at the request of the Team may result in injury to him. Accordingly, the Player agrees that he will not, without the written consent of the Team, engage in any activity that a reasonable person would recognize as involving or exposing the participant to a substantial risk of bodily injury including, but not limited to: (i) sky-diving, hang gliding, snow skiing, rock or mountain climbing (as distinguished from hiking), rappelling, and bungee jumping; (ii) any fighting, boxing, or wrestling; (iii) driving or riding on a motorcycle or moped; (iv) riding in or on any motorized vehicle in any kind of race or racing contest; ( $v$ ) operating an aircraft of any kind; (vi) engaging in any other activity excluded or prohibited by or under any insurance policy which the Team procures against the injury, illness or disability to or of the Player, or death of the Player, for which the Player has received written notice from the Team prior to the execution of this Contract; or (vii) participating in any game or exhibition of basketball, football, baseball, hockey, lacrosse, or other team sport or competition. If the Player violates this Paragraph 12, he shall be subject to discipline imposed by the Team and/or the Commissioner of the NBA. Nothing contained herein shall be intended to require the Player to obtain the written consent of the Team in order to enable the Player to participate in, as an amateur, the sports of golf, tennis, handball, swimming, hiking, softball, volleyball, and other similar sports that a reasonable person would not recognize as involving or exposing the participant to a substantial risk of bodily injury.

57. National Hockey League, Collective Bargaining AgreEment (2005). 
However, unless it is clearly defined in an agreement, what exactly is a hazardous activity? Is celebrating a great play hazardous? Are engaging in practical jokes hazardous? Consider that in 2010, Los Angeles Angels of Anaheim first baseman Kendry Morales hit a walk-off grand slam homerun, but as he jumped in the air to touch home plate, and surrounded by his teammates, he fractured his leg. ${ }^{58}$ Similarly, the NFL's Arizona Cardinals' placekicker Bill Gramatica tore his anterior cruciate ligament (ACL) in 2001 in a game against the New York Giants after kicking a 42-yard field goal and jumping in jubilation. ${ }^{59}$ Are these types of celebratory antics or activities what contract drafters might predict to happen and subsequently provide for it in a contract in order to protect a client? Probably not, but it certainly proves the point: defining what a hazardous activity is can be a curious challenge.

The scope of hazardous activity clauses reached comical proportions in recent years starting with the manner in which Detroit Tigers lost relief pitcher Joel Zumaya in 2006 for three games of the American League Championship Series due to an activity that would not normally be characterized as a hazardous one: he was injured while playing a PlayStation 2 video game called Guitar Hero and suffering inflammation in his right (throwing) wrist and forearm. ${ }^{60}$ In 2008, two-time Olympic gold medalist Misty May-Treanor ruptured her left Achilles tendon while rehearsing for the popular television show, "Dancing with the Stars." ${ }^{.61}$ In 2010, Florida Marlins player Chris

58. See Lyle Spencer, Kendry's Walk-off Slam Comes with Injury, MLB.Com (May 29, 2010), http://mlb.mlb.com/news/article.jsp?ymd $=20100529 \&$ content id $=10569596 \&$ vkey=recap\&fext $=$.jsp \&c_id=mlb; see also MAJOR LEAGUe BASEBALl, COLlective BARGaining AgreEMENT, 20072011. Paragraph 5(b) ("Other Sports") of the MLB Uniform Player's Contract actually states that "Player agrees that he will not engage in professional boxing or wrestling; and that, except with the written consent of the Club, he will not engage in skiing, auto racing, motorcycle racing, sky diving, or in any game or exhibition of football, soccer, professional league basketball, ice hockey or other sport involving a substantial risk of personal injury.").

59. Associated Press, NFL Notebook: Gramatica's Celebration Costs Cardinals, SEATTLEPI.COM (Dec. 18, 2001), available at http:/www.seattlepi.com/football/51044_nfln I8.shtml; see also National Football League Collective Bargaining Agreement, 2006-2012. Paragraph 3 ("Other Activities") of the NFL's standard player contract provides the general language related to prohibited activities. The Paragraph prohibits any activity involving "significant risk of personal injury" outside of playing football.

60. See Christopher L. Gasper, Virtually Perfect, Boston GLoBE (July 20, 2007), available at http://www.boston.com/sports/football/patriots/articles/2007/07/20/virtually_perfect/.

61. See Bill Keveney, Injury Forces Moy-Treanor to Sit Out This 'Dancing, 'USA ToDAY (Oct. 8, 2008), available at http://www.usatoday.com/life/television/news/2008-10-06-may-treanorinjury_N.htm. 
Coghlan tore a meniscus in his left knee when delivering a shaving cream pie to the face of a teammate who hit a walk-off single to win the game. ${ }^{62}$

An analysis and comparison of the big four hazardous activity clauses offers an excellent opportunity for students and professors to query why such provisions are included in standard player contracts. It also allows consideration of sports other than the big four and how such standard player agreements (or sponsorship agreements) might address the concerns. Certainly, hazardous activity clauses are meant to serve as a deterrent so that players do not put themselves in position of physical harm outside the scope of their game.

\section{TERMINATION FOR "CAUSE" CLAUSES}

The right to end the business or working relationship is a natural consideration for the contract drafters and the parties themselves. For example, stadium and arena leases, operating and naming rights for such venues, and investment in teams are often long term, but good contract drafters include provisions that might allow the parties to terminate their relationship early if necessary. ${ }^{63}$ In fact, the failure to properly draft a contract with such high stakes could lead to malpractice lawsuit. ${ }^{64}$ In the employment context, a "with cause" or "for cause" termination of the relationship between employer and employee (or endorser and endorsee) might be necessary to protect the image of a club, sponsor or institution for misconduct by the employee at all levels. ${ }^{65}$

Defining the word "cause" regardless of how it is characterized can present problems, however. The termination for cause clause has largely appeared in college sports in recent years for violations of NCAA bylaws, calling into question which party-the athletic director or the coach-has the

62. See Nick Coman, Chris Coghlan Tears Meniscus Throwing Pie as Celebration-Induced Injury Strikes Again, NESN (July 27, 2010), http://www.nesn.com/2010/07/chris-coghlan-tearsmeniscus-throwing-pie-as-celebrationinduced-injury-strikes-again.html.

63. See, e.g., Kristi E. Swartz, Lawsuit: Thrashers Owners Have Been Trying to Sell Team Since 2005, ATLANTA JOURNAL CONSTITUTION (Jan. 21, 2011), available at http://www.ajc.com/sports/lawsuit-thrashers-owners-have-811606.html? cxtype=rss_news.

64. Id. (discussing the ownership group of the NHL's Atlanta Thrashers who filed a $\$ 200$ million lawsuit against the law firm King \& Spalding alleging negligence in drafting the appraisal and buyout process if the owners wanted to sell their financial interest).

65. See, e.g., Alexis Stevens, Damon Evans Ex-UGA Athletic Director Pleads Guilty to DUI Charge, ATLANTA JOURNAL CONSTITUTION (Jan. 26, 2011), available at http://www.ajc.com/news/damon-evans-ex-uga-816707.html. 
upper-hand when it comes to contract negotiations particularly involving for cause, with cause, or even what happens when it is without cause. ${ }^{66}$

A discussion of the following college coaches represents some of the more prominent and interesting "for cause" termination situations in recent years with many instances of settlement rather than litigation. ${ }^{67}$ As expected, some of the firings sparked lawsuits. ${ }^{68}$ An employee, such as a college coach, is not defenseless when the employer-university alleges a breach of the contract triggering possible "for cause" termination justification. Still, college coaches are quite familiar with the carousel involved in the employment and termination in their profession. ${ }^{69}$ Consider how the respective universities differed in their approach to dealing with the termination of their head basketball coaches and the events that followed the terminations in the O'Brien, Sampson and Pearl triumvirate.

\section{A. Jim O'Brien}

The Ohio State University (OSU) head basketball coach Jim O'Brien was fired, though there were still three years remaining on his contract, by its athletic director Andy Geiger in 2004 after he admitted giving a $\$ 6,000$ loan to a prospective Serbian recruit back six years prior. ${ }^{70} \mathrm{O}$ Brien, in response, sued alleging that OSU could not terminate him even if he allegedly violated NCAA rules unless he had committed a material breach of his contract. ${ }^{71}$ An

66. See, e.g., Brent C. Moberg, Navigating the Public Relations Minefield: Mutual Protection Through Mandatory Arbitration Clauses in College Coaching Contracts, $16 \mathrm{~J}$. LEGAL ASPECTS OF SPORT 85 (2006) (referencing inaccuracies on Coach George O'Leary's resume resulting in only a five-day tenure as the head football coach); see also Rodgers v. Georgia Tech Athletic Ass'n, 303 S.E.2d 467 (Ga. Ct. App. 1983) (firing without cause); but see Cole v. Valley Ice Garden, 113 P.3d 275 (Mont. 2005) (firing for "just cause" was legitimate due to poor win-loss record).

67. Associated Press, Bobby Gonzalez, Seton Hall Settle, ESPN (Aug. 17, 2010), http://sports.espn.go.com/new-york/news/story?id=5471121 (noting that school officials referred to off-court problems when they announced his firing and he claimed in his lawsuit that he had been fired without cause and was owed two years of salary).

68. Id.; see also Mark Alesia, IUPUI: Paying Coach Shann Hart $\$ 300,000$ Beat Being Sued, INDIANAPOLIS STAR (Sept. 25, 2010), available at http://iphone.indystar.com/posts/39987 (noting that IUPUI fired its women's basketball "without cause" by buying her out rather than firing her for cause).

69. See generally Richard T. Karcher, The Coaching Carousel in Big-Time Intercollegiate Athletics: Economic Implications and Legal Considerations, 20 FORDHAM INTELL. PROP. MEDIA \& ENT. L.J. 1 (2009).

70. O’Brien v. Ohio State Univ., 2007-Ohio-4833, 2007 Ohio App. LEXIS 4316 (Ct. App. 2007).

71. Id. \ 1. The court noted that in OSU could not terminate O'Brien without "cause," which was defined in Section 5.1 of his contract as, 
Ohio trial court held that the violation of NCAA rules (and the egregious failure to disclose the violation) was not, in fact, a material breach of the contract and therefore OSU could not utilize a for cause termination on that basis alone. ${ }^{72}$

On appeal, OSU was forced to pay O'Brien approximately $\$ 2.5 \mathrm{M}$, which included interest, for the breach of the contract though the court did not ratify or condone his misconduct O'Brien. ${ }^{73}$ In fact, the Court of Appeals of Ohio noted, "OSU was the drafting party. OSU is not lacking in sophistication, and has only been prejudiced as a result of being held to its own bargain." "74 O'Brien's case set an example for university counsel, athletic directors and contract drafters to consider ways to tighten college coaching contracts. ${ }^{75}$ Subsequently, O'Brien's replacement, Coach Thad Matta, has 15 grounds for termination in his agreement. ${ }^{76}$

\section{B. Kelvin Sampson}

Indiana University (IU) paid men's head basketball coach Kelvin Sampson $\$ 750,000$ to leave Bloomington in 2008. ${ }^{77}$ Sampson had just replaced Coach Mike Davis, and Sampson's contract was drafted so that he could be fired for "just cause" which was defined in several ways in fourteen subsections, including

...(4) A significant, intentional, or repetitive violation of any law, rule, regulation, constitutional provision, bylaw or interpretation of the

Termination for Cause - Ohio State may terminate this agreement at any time for cause, which, for the purposes of this agreement, shall be limited to the occurrence of one or more of the following: (a) a material breach of this agreement by Coach, which Coach fails to remedy to OSU's reasonable satisfaction, within a reasonable time period, not to exceed thirty (30) days, after receipt of a written notice from Ohio [S]tate specifying the act(s), conduct or omission(s) constituting such breach; (b) a violation by Coach *** of applicable law, policy, rule or regulation of the NCAA or the Big Ten Conference which leads to a "major" infraction investigation by the NCAA or the Big Ten Conference and which results in a finding by the NCAA or the Big Ten Conference of lack of institutional control over the men's basketball program or which results in Ohio State being sanctioned by the NCAA or the Big Ten Conference....

The court further noted, however, that OSU could terminate O'Brien without cause, but, if so, it would be obligated to pay O'Brien liquidated damages. Id. at $\uparrow 15-16$.

72. Id. $\uparrow 2,15$.

73. Id. 3 .

74. Id. 995.

75. See Martin J. Greenberg, Termination of College Coaching Contracts: When Does Adequate Cause to Terminate Exist and Who Determines Its Existence?, 17 MARQ. SPORTS L. REV. 197 (2006)

76. Id. at 218-21.

77. ESPN.com News Services, Indiana, Sampson reach $\$ 750,000$ Settlement to Part Ways, ESPN (Feb. 23, 2008), http://sports.espn.go.com/ncb/news/story?id=3258506. 
University, the Big Ten Conference or the NCAA, which violation may, in the sole judgment of the University, reflect adversely upon the University or its athletic program, including but not limited to any significant, intentional, or repetitive violation which may result in the University being placed on probation by the Big Ten Conference or the NCAA and including any violation which may have occurred during any prior employment of the Employee at another NCAA member institution and for which the NCAA could hold the Coach responsible ${ }^{78}$

It also included a just cause termination provision for the general "failure to maintain an environment in which the coaching staff complies with NCAA, Big Ten and University rules and regulations. ." 79 Prior to his hire at IU, Sampson had been directly involved in NCAA violations at the University of Oklahoma, his previous employer, and yet Indiana gave Sampson a second chance though it clearly wanted to protect itself against Sampson's previous transgressions. ${ }^{80}$ Sampson had made nearly 600 phone calls to recruits in violation of NCAA while he was the head coach at the University of Oklahoma, and Indiana's new coach was punished even before he coached his first game at IU. ${ }^{81}$

Shortly thereafter, IU conducted an investigation in which Sampson and his IU staff made yet more phone calls in violation of NCAA rules, again, and even though Sampson did not make call himself, he appeared on the three-way calls to recruits. ${ }^{82}$ Sampson and his staff engaged in five major violations. ${ }^{83}$ Sampson was summarily paid to leave and agreed not to file a wrongful termination suit against IU ${ }^{84} \mathrm{IU}$ was willing to pay the price, if necessary, by hiring a coach who left a program under investigation by the NCAA. In the end, IU did.

78. Greenberg, supra note 75 , at $212-14$ (referencing number 4 of the 14 ways that might trigger a "just cause" termination of Sampson's agreement).

79. Id. at 214 (referencing number 11 of the 14 ).

80. Id. at 214-15.

81. Associated Press, Sampson Barred from Off-Campus Recruiting, ESPN (May 26, 2006), http://sports.espn.go.com/ncb/news/story?id $=2457878$.

82. ESPN.com News Services, supra note 77.

83. Id.

84. Id. 


\section{Bruce Pearl}

No stranger to controversy, head basketball coach Bruce Pearl was hired by the University of Tennessee (UT) in $2005 .{ }^{85}$ After lying to the NCAA over reports over alleged recruiting violations by Pearl, athletic director Mike Hamilton sanctioned the charismatic Pearl and ultimately terminated his contract in $2010 .^{86}$ However, Pearl's contract protected the coach even though he admitted that he deliberately misled NCAA investigators while they were pursuing allegations of recruiting violations by Pearl. ${ }^{87}$ Oddly, Hamilton terminated the agreement but he did not terminate Pearl. ${ }^{88}$ UT could not terminate coach Bruce Pearl for cause until was an NCAA finding. ${ }^{89}$ Even if there was a finding, it had to be determined that Pearl knowingly engaged in conduct that was a significant $\mathrm{NCAA}$ violation. ${ }^{90}$

Southeastern Conference (SEC) Commissioner Mike Slive, however, suspended Pearl for the first eight games of the 2010-11 conference schedule because of the misconduct during the NCAA investigation. ${ }^{91}$ Pearl agreed to coach under a Letter of Appointment until a new contract would be (supposedly) agreed-upon. ${ }^{92}$ Clearly, Pearl remained the head coach because Hamilton wanted it that way. ${ }^{93}$ Comparing the above termination situations allows for an exploration of different methods of exercising the for cause

85. See, e.g., Marlen Garcia, Ex-coach Jimmy Collins Shows No Sympathy for Bruce Pearl, USA TODAY (Sept. 20, 2010), available at http://www.usatoday.com/sports/college/mensbasketball/2010 09-12-jimmy-collins-bruce-pearl_N.htm. (discussing Pearl's role, when he was an assistant coach at the University of lowa, in reporting NCAA rules violations involving the University of lllinois); see also Michael Ellis, Bruce Pearl Era at Tennessee Might Be Coming To An End, BLEACHER REPORT (Dec. 23, 2010), http://bleacherreport.com/articles/550645-bruce-pearl-era-at-tennessee-may-bedrawing-near-to-the-end.

86. Ellis, supra note 85; see also Mike Griffith, UT Terminated Pearl's Contract but Working on New One, GOVOLSXTRA (Oct. 21, 2010), http://www.govolsxtra.com/news/2010/oct/21/utterminated-pearls-contract-working-new-one/.

87. See Andy Katz, Bruce Pearl Protected by Contract, ESPN (Sept. 17, 2010), http://sports.espn.go.com/ncb/news/story?id=5582439 (noting that Pearl hosted recruits at his house in 2008 for unofficial visits and then lied about a photo taken at his house demonstrating otherwise).

88. Griffith, supra note 86 (quoting Hamilton as stating, "It doesn't change our stance that we want Bruce Pearl to be our basketball coach for months and years to come...").

89. Katz, supra note 87.

90. Id.

91. See ESPN.com News Services, SEC Suspends Pearl 8 Games, ESPN (Nov. 20, 2010), http://sports.espn.go.com/ncb/news/story?id $=5824966$.

92. Griffith, supra note 86.

93. Id. Pearl, however, was permanently relieved of his duties and his employment at the University of Tennessee following a first-round loss in the 2011 NCAA "March Madness" basketball tournament. 
termination clause. In the cases involving O'Brien, Sampson and Pearl, each represented a different outcome once the desire to enforce the for cause termination provision was exercised. Some college coaches, as demonstrated by the O'Brien example, fight back rather than settle with the university ${ }^{94}$ The partial roster of others might include, for example, Mike Leach, ${ }^{95}$ Rick Neuheisel, ${ }^{96}$ Billy Gillispie, ${ }^{97}$ Jim Leavitt, ${ }^{98}$ Mark Mangino, ${ }^{99}$ and Tim Cohane, ${ }^{100}$ just to name a few. All of these examples could serve as research projects for students related to worthwhile exploration of special circumstances, termination issues and contract clauses in each instance.

\section{MORALS CLAUSES}

Another clause worth exploring is known as the morals clause sometimes referred to as moral turpitude or morality clause. ${ }^{101}$ This clause, unlike the hazardous activity clause, involves a morals-based provision that has generated considerable discussion in sports and the law though it has its roots in the entertainment industry. ${ }^{102}$ In the NFL, ${ }^{103} \mathrm{NBA},{ }^{104} \mathrm{MLB},{ }^{105}$ and the

94. O’Brien v, Ohio State Univ., 2007 Ohio 4833 (Ct. App. 2007); see also, Van Breda Kolff v. St. Bonaventure Univ., CV 04-03270 (W.D.N.Y. 2003).

95. ESPN.com News Services, Mike Leach Plans to Appeal, ESPN (Jan. 21, 2011), http://sports.espn.go.com/ncf/news/story?id $=6044702$ (noting that Texas Tech University fired football coach Mike Leach in 2009 a day before he was to receive an $\$ 800,000$ bonus and was fired "for cause" for his alleged treatment of Adam James, son of ESPN broadcaster Craig James, by sending him to the equipment garage while the rest of the team practiced).

96. Associated Press, Neuheisel Says He Feels Vindicated by Settlement, ESPN (Mar. 8, 2005), http://sports.espn.go.com/nef/news/story?id=2007123.

97. ESPN.com News Services, Gillispie, Kentucky Part Ways, ESPN (Mar. 28, 2009), http://sports.espn.go.com/ncb/news/story?id=4021232.

98. Greg Auman, USF Settles Ex-coach Jim Leavitt's Lawsuit for $\$ 2.75$ Million, ST. PETERSBURG Times (Jan. 12, 2011), available at http://www.tampabay.com/sports/college/usf-settlesex-coach-jim-leavitts-lawsuit-for-275-million/1144945 (noting that the USF investigation found he committed "serious violations" of the school's conduct policy and was fired "with cause").

99. ESPN.com News Services, Mangino Out at Kansas, ESPN (Dec. 4, 2009), http://sports.espn.go.com/ncf/news/story?id=4711389.

100. Cohane v. NCAA, 2007 U.S. App. LEXIS 1841 (2d Cir. 2007), cert. denied, 2007 U.S. LEXIS 12179 (2007).

101. See generally Porcher L. Taylor, III, Fernando M. Pinguelo \& Timothy D. Cedrone, The Reverse-Morals Clause: The Unique Way to Save Talent's Reputation and Money in a New Era of Corporate Crimes and Scandals, 28 CARDOZO ARTS \& ENT. L.J. 65 (2010).

102. Id. (stemming from embarrassing antics of actors particularly after the infamous litigation involving Roscoe "Fatty" Arbuckle who had been accused of heinous crimes though he was later cleared of the charges); see also Nader v. ABC Television, Inc., 150 Fed. Appx. 54 (2d Cir. 2005).

103. See, e.g., Marc Edelman, Are Commissioner Suspensions Really Any Different from Illegal Group Boycotts? Analyzing Whether the NFL Personal Conduct Policy Illegally Restrains Trade, 58 
NHL, ${ }^{106}$ morals clauses are found not only in the respective league constitutions, in which case it relates to the power granted to the league Commissioner, but also in the standard individual player contracts, in which it may apply to the players and their individual teams. ${ }^{107}$ For example, Article 35 of the NBA Constitution allows the Commissioner to suspend or fine a player who, ". . . in his opinion. . shall have been guilty of conduct that does not conform to standards of morality or fair play, that does not comply at all times with all federal, state, and local laws, or that is prejudicial or detrimental to the Association." 108

It is important to recognize that just because a morals clause may exist in an agreement does not necessarily mean that it has to be exercised by the nonbreaching party. Like the hazardous activity clause, it may merely serve as a deterrent to misconduct. Students might compare and contrast the scope of the relevant big four provisions with regard to misconduct and the degree to which conduct is defined, as written in the league constitution or collective bargaining agreement, between on-the-field and off-the-field behavior. ${ }^{109}$ While the big four sports have morals clauses in various places in their collective bargaining agreements or standard player contracts, numerous

CATH. U.L. REV. 631, 638 (2009) (recognizing that the NFL's COLLECTIVE BARGAINING AGREEMENT 2006-2012, app. C, para. 15, at 253, allows the Commissioner to suspend a player for "conduct detrimental to the integrity of and public confidence in the National Football League.").

104. See Greenberg, supra note 75 , at 69 (noting that by amendment to its Collective Bargaining Agreement, Section 5 of the NBA Standard Player Contract requires a player "to be neatly and fully attired in public and always to conduct himself on and off the court according to the highest standards of honesty, morality, fair play and sportsmanship.").

105. See Jan Stiglitz, Player Discipline in Team Sports, 5 MARQ. SPORTS L.J. 167, 170 (1995) (noting that in section 7(b)(1) of the Uniform Player's Contract, an MLB team can void a contract if a player fails, refuses or neglects to "conform his personal conduct to the standards of good citizenship and good sportsmanship or to keep himself in first-class physical condition or to obey the Club's training rules.").

106. See Matthew J. Parlow, Professional Sports League Commissioners' Authority and Collective Bargaining, 11 TEX. REV. ENT. \& SPORTS L. 179, 185 (2010) (referencing NATIONAL HOCKEY LEAGUE BYLAWS $\S 17.3$ (a) (1990) (authorizing the NHL Commissioner to punish an athlete "whether during or outside the playing season has been dishonorable, prejudicial to or against the welfare of the League or the game of Hockey.").

107. Stiglitz, supra note 105 , at 169-170.

108. See David Sirotkin, Disciplining the Disciplinary Systems in Professional Sports: An Attempt to Fix the Arbitrary and Overreaching Disciplinary Powers of Sports Commissioners, 11 CARDOZO J. CONFLICT RESOL. 289, 295-6 (2009) (noting that players agree to abide by the NBA Constitution through their individual player contracts).

109. See, e.g., Foote, supra note 44, at 35 (noting that Boston Red Sox player Wil Cordero pled guilty to abusing his wife and was suspended for several games); see also Roger A. Javier, "You Cannot Choke Your Boss \& Hold Your Job Unless You Play in the NBA": The Latrell Sprewell Incident Undermines Disciplinary Authority in the NBA, 7 VILL. SPORTS \& ENT. L.J. 209 (2009). 
prominent athletes have lost endorsements and sponsorships as a result of the exercise of a morals clause in a contract. ${ }^{110}$ This list includes, among others, golfer Tiger Woods, ${ }^{111}$ Michael Vick, ${ }^{12}$ and swimmer Michael Phelps. ${ }^{113}$ It might be a worthwhile to explore the specific reasons and circumstances behind the terminations among others in varied contexts. ${ }^{114}$

\section{ADDITIONAL CLAUSES}

The above sections demonstrated some of the most prominent clauses found in the context of sports and the law. However, there are certainly many others one could pursue. For instance, an examination of the importance of the integrity clause as a condition of eligibility for the Heisman Trophy became a centerpiece of national discussion 2010 when Auburn University quarterback Cam Newton won the award even though Newton was involved in past scandalous activity, not to mention his father was involved in a pay-for-play scheme involving the recruitment of his son to various institutions of higher learning. ${ }^{115}$

For the contract drafter, the student, professor, or merely the curious, some of the other interesting and entertaining contract clauses worth exploring might include the weight, ${ }^{116}$ one-way, ${ }^{117}$ two-way, ${ }^{118}$ ten-day, ${ }^{119}$ emergency, ${ }^{120}$

110. See Taylor, III, Pinguelo \& Cedrone, supra note 101, at 66-73 (offering that morals clauses work both ways and that "reversemmorals clauses" afford athletes, entertainers, and other talent, the ability to save their own reputation in an era of corporate scandals and crimes such as the one involving Enron).

111. Id. at 99-100 (exploring and characterizing Tiger Woods and his reputation "pre-scandal").

112. Id. at 102-104 (referencing Vick's involvement in a dog-fighting conspiracy).

113. See CNN, Phelps Suspended from Competition, Dropped by Kellogg, CNN.COM (Feb. 6, 2009), http://www.cnn.com/2009/US/02/05/kellogg.phelps.

114. See, e.g., Maddox v. Univ. of Tenn., 62 F.3d 843 (6th Cir. 1995) (affirming decision by the district court, which held that Maddox was not terminated solely by reason of, or because of, his handicap, but rather because of a well-publicized incident in which he was arrested for driving under the influence of alcohol).

115. See Associated Press, Cam Newton Wins Heisman Trophy, ESPN (Dec. 13, 2010), http://sports.espn.go.com/nef/news/story?id=5909569; see also Tom Weir, Cam Newton Left Off At Least 6 Heisman Ballots, USA TODAY (Dec. 7, 2010), available at http:/content.usatoday.com/ communities/gameon/post/2010/12/cam-newton-heisman-trophy-ballots/1; see also Heisman Trophy, Heisman Trust Mission Statement, http:/www.heisman.com/trust/mission statement.php (last visited Jan. 29, 2011) ("The Heisman Memorial Trophy annually recognizes the outstanding college football player whose performance best exhibits the pursuit of excellence with integrity. Winners epitomize great ability combined with diligence, perseverance and hard work. The Heisman Trophy Trust ensures the continuation and integrity of this award...").

116. See James Walker, Sources: Smith Has Weight Clause, ESPN (Sept. 1, 2009), http://sports.espn.go.com/nf1/trainingcamp09/news/story?id=4437525. 
most favored nation, ${ }^{121}$ arbitration, ${ }^{122}$ attendance, ${ }^{123}$ and no-contact-withrecruits clauses. ${ }^{124}$ If time allows, it could be worth exploring the relationship between the prospective student-athlete-by way of the National Letter of Intent (NLI) program-and the college or university. ${ }^{125}$ This is a voluntary program which commits a prospective student-athlete, in writing, to an institution for just a year's worth of financial aid for an athletic scholarship. ${ }^{126}$ However, there has been criticism as to the fairness and legitimacy of both the NLI program and the promises made during the recruiting process overall. ${ }^{127}$ Once committed to the institution, some authors have referred to the additional waivers related to student-athletes who sign consent forms to use their name, image and likeness without limits, as being unconscionable and one of adhesion. ${ }^{128}$ This might be especially significant in light of the deep chasm

117. See Brian Roe, Predators Report: The Two-Way Contract Dilemma, HockeY's FUTURE (May 27, 2002), available at http://www.hockeysfuture.com/articles/4553/ predators_report_the_twoway_contract_dilemma/.

118. Id.

119. See Associated Press, Suns Sign Guard Dowdell to Second 10-day Contract, SI.COM (Jan. 27, 2011) available at http://sportsillustrated.cnn.com/2011/basketball/nba/01/27/dowdell. suns.ap/index.html.

120. See ESPN.com News Services, Tom Fenton Found, Signed by Coyotes, ESPN (Dec. 17, 2010), http://sports.espn.go.com/nhl/news/story?id=5927810.

121. See Mark Snyder, U-M Partners with Adidas, DeTroIt Free-Press (July 11, 2007), at Sports, p. 2 (noting that the university has a most favored nation clause committing Adidas to keeping it as the top college under contract with the company).

122. See, e.g., Boston Celtics Ltd. P'ship v. Brian Shaw, 908 F.2d 1041 (1 st Cir. 1990).

123. See Adam Bernacchio, Johnny Damon and Manny Ramirez Sign with the Rays: Reunited and it Feels So Good, BLEACHER REPORT (Jan. 21, 2011), http://bleacherreport.com/articles/582071reunited-and-it-feels-so-good-johnny-damon-and-manny-ramirez-sign-with-the-rays.

124. See Dan Fitzgerald, A More Detailed Look at Marist v. Brady, CONNECTICUT SPORTS LAW (Aug. 6, 2009), available at http://ctsportslaw.com/2009/08/06/a-more-detailed-look-at-marist-vbrady/.

125. See Katherine Sulentic, Running Backs, Recruiting, and Remedies: College Football Coaches, Recruits, and the Torts of Negligent and Fraudulent Misrepresentation, 14 ROGER WILLIAMS U.L. REV. 127 (2009).

126. Id. at 146-47; see also Luke DeCock, Letter of Intent in College Athletics is Faulty, CHARLOTTE OBSERVER (Aug. 10, 2010), available at http://www.charlotteobserver.com/2010/ 08/08/1608585/letter-of-intent-faulty.html.

127. See, e.g., Jamie Y. Nomura, Refereeing the Recruiting Game: Applying Contract Law to Make the Intercollegiate Recruitment Process Fair, 32 HAWAII L. REV. 275 (2009).

128. See generally Kristal S. Stippich \& Kadence A. Otto, Carrying a Good Joke Too Far? An Analysis of the Enforceability of Student-Athlete Consent to Use of Name \& Likeness $20 \mathrm{~J}$. LEGAL ASPECTS OF SPORT 151 (2010) (exploring four arguments under which a court could find that the student-athlete's consent is unenforceable). 
that exists between the ideals of amateurism and the reality of big-time commercialization of intercollegiate sport in the United States. ${ }^{129}$

\section{A. Liquidated Damages Clauses}

A typical liquidated damages clause allows the parties to privately agree what a "penalty" will be for a breach of the agreement. ${ }^{130}$ Though not designed to be punitive in nature, it can have the same effect and impact. ${ }^{131}$ Good contract drafters provide liquidated damages clauses and they are quite effective when utilized. ${ }^{132}$ Liquidated damages also provide a measure of financial certainty at the outset for the parties, such as the loss of a coach to another institution or in the event of a cancellation of a contest, and calculating damages without a liquidated damages provision could prove to be extremely difficult. $^{133}$

In 2008, a liquidated damages provision was the centerpiece of litigation involving the University of Louisville which sued Duke University for breach of contract as a result of Duke's decision to cancel football games against Louisville that had been scheduled for 2007, 2008, and 2009 under a contract signed in 1999. ${ }^{134}$ Following a 2002 game, Duke cancelled the remaining games of the series under Paragraph 13 of the Athletic Competition Agreement, and a liquidated damages sum of $\$ 150,000$ was required to be paid per game to the non-breaching party. ${ }^{135}$ However, the contract excused the party from paying if the non-breaching university (Louisville) was able to

129. Id.; see also Timothy Epstein, Splinters from the Bench: Feasibility of Lawsuits by Athletes Against Coaches and Schools for Lack of Playing Time, 4 VA. SPORTS \& ENT. L. J. 174 (2005).

130. See generally Vanderbilt Univ. v. DiNardo, 174 F.3d $751 \quad\left(6^{\text {th }}\right.$ Cir. 1999) (rejecting DiNardo's assertion that the liquidated damages provision found in his contract was a penalty and should not be enforced. DiNardo left for Louisiana State University, and the Sixth Circuit held that the provision was indeed reasonable).

131. Id.; see also Karcher, supra note 69, at 47-54.

132. Karcher, supra note 69, at 51-54 (discussing the case involving West Virginia University suing its former football coach Rich Rodgriguez for liquidated damages after he felt it was better to take the head coach position at the University of Michigan); see also Joel Barker, Tennessee Cancels UNC Series: Time for Vols to Leave SEC or Fire AD, BLEACHER REPORT (Aug. 17, 2010), $\mathrm{http} / /$ bleacherreport.com/articles/438109-tennessee-cancels-unc-series-time-for-vols-to-move-on (discussing University of Tennessee Athletic Director Mike Hamilton's decision to exercise rights under a liquidated damages clause that required a payment to the University of North Carolina in the amount of $\$ 1.5$ million to cancel a home and away series in 2011-2012).

133. Karcher, supra note 69, at 54-58; see also O'Brien, 2007 Ohio at 5.

134. University of Louisville v. Duke Univ., No. 07-Cl-1765 (Franklin Cir. Ct. June 19, 2008).

135. Id at 2-3; see also Associated Press, Louisville Files Lawsuit Claiming Breach of Contract, ESPN (Nov. 8, 2007), http://sports.espn.go.com/ncf/news/story?id=3100938 (noting that Louisville added Murray State to its schedule for 2007). 
show that it was able to schedule a replacement game "with a team of similar stature." $" 136$

The Kentucky court, recognizing that Duke only won one football game in 2007, agreed with Duke that there was no worse team in Division I football and Duke was excused from paying the liquidated damages since Louisville did fill its schedules with replacements for 2007 and 2008 and that it made no attempt to demonstrate that any of the replacements were inferior than the Duke football team. ${ }^{137}$ The state court granted Duke's motion for summary judgment with prejudice against Louisville for the 2007 and 2008 seasons and without prejudice for $2009 .{ }^{138}$ An exploration of this lawsuit demonstrates the value that such provisions have for the parties involved and how vitally important defining terms and phrases in a contract can be. ${ }^{139}$

\section{B. Force Majeure Clauses}

A workable definition of force majeure can include, "[a]n unforeseeable natural or human event beyond the control of the parties to a contract, rendering performance of the contract impossible." 140 Also known as "acts of God" or "weather clauses," force majeure clauses deal with how to address contractual obligations when a triggering event affects the obligation of the parties. ${ }^{141}$ Good contract drafters must consider various issues which could trigger a force majeure provisions. ${ }^{142}$ Force majeure clauses might address suspension of or excusing performance by internal or external forces. ${ }^{143}$ Force majeure clauses are often "thrown-in" as standard boilerplate language related to the rescheduling or delaying of events yet rarely implemented in sports contracts. ${ }^{144}$ This may be due to the nature of sports contests having to reschedule at a moment's notice.

136. University of Louisville, . No. 07-Cl-1765 at 2-3 (interpreting the phrase "team of similar stature" to mean that "the two are on the same level.").

137. Id. at 3-6.

138. Id. at 8-9.

139. See, e.g., Aaron McMann, Vague Language in Football Contract with IU May Not Bring Results, CENTRAL MiCHIGAN LIFE (July 14, 2010), available at http:/www.cmlife.com/2010/07/14/vague-language-in-football-contract-with-iu-may-not-bring-results/.

140. See Gary D. Way, Sudden Death: League Labor Disputes, Sports Licensing and Force Majeure Neglect, 7 MARQ. SPORTS L.J. 427 (1997) (citing RANDOM HOUSE LEGAL DICTIONARY 101 ( ${ }^{\mathrm{st}}$ ed. 1996)).

141. Id. at 427 .

142. Id at $440-44$.

143. Id at 454-56.

144. Id. at 427 . 
In Bouchard Transp. Co. v. N.Y. Islanders Hockey Club, for example, the transportation company attempted to sue the NHL team for breach of contract during the infamous 2004-2005 season in which the NHL owners instituted a locked. Ultimately, the court of appeals sided with the Islanders since there was a clause in a lease agreement which absolved the hockey club from liability for non-performance caused by a force beyond the club's control, such as a labor dispute, thus a force majeure. ${ }^{145}$ The NHL lockout made it impossible for the Islanders to play other teams since there were no games. ${ }^{146}$

Students and professors might explore other situations in which a force majeure clause might excuse or suspend performance of a contractual obligation, terminate an agreement, receive a credit or rebate of some sort, or allow for an equitable adjustment of the contract itself. ${ }^{147}$ Asking students about how snowstorms, meteor strikes, labor strikes (i.e., "work stoppages"), flooding, hurricanes, tornadoes, bee swarms, jelly-fish attacks, tsunamis and any other possibility that might delay a sporting event including the spread of bacterial infections even air or water pollution should provide an invitation to creative class participation and a lot of potential research projects. For starters, in 2010 the Minnesota Vikings football team was the beneficiary of two snowrelated incidents in the same season causing a small degree of scheduling chaos starting with the collapse of the Metrodome roof after a huge snowstorm. ${ }^{148}$

\section{Best Efforts Clauses}

A "best efforts" clause is one which mandates general acts of good faith by each party to an agreement. ${ }^{149}$ There is no specific formula as to what

145. Bouchard Transp. Co, v. N.Y. Islanders Hockey Club, 836 N.Y.S.2d 654 (App. Div. 2007).

146. Id.

147. Way, supra note 140 , at 454.

148. See ESPN.com News Services, Giants-Vikings Moved to Ford Field, ESPN (Dec. 13, 2010), http://sports.espn.go.com/nfl/news/story?id=5911532; see also Deborah Barrington, NFL Postpones Vikings-Eagles to Tuesday Because of Snow, USA TODAY (Dec. 26, 2010), available at http:/content.usatoday.com/communities/thehuddle/post/2010/12/blizzard-pushes-vikings-and-eagles -to-tuesday-night/1. Subsequently, the game against the New York Giants was suspended and moved indoors to Ford Field in Detroit on Monday night. The Vikings were informed that the roof still could not be fixed so the Monday night game against the Chicago Bears was moved to the University of Minnesota's TCF Bank Stadium. Then, blizzard conditions in Philadelphia the next week caused the NFL to reschedule the game against the Eagles from Sunday to Tuesday night in Philadelphia in the name of public safety.

149. See generally Triple-A Baseball Club Assocs. v. Northeastern Baseball, Inc., 832 F.2d 214, 225-27 (1st Cir. 1987) (comparing "best efforts" involving obtaining minor sale and subsequent league approval of a baseball franchise to that of the Maine Uniform Commercial Code $\$ 2-306$ involving output, requirements and exclusive dealings contracts); see also Martin J. Greenberg, 
constitutes best efforts: it depends upon the nature of the facts, industry or sport and relevant field of law. ${ }^{150}$ The big four sports leagues have examples of best efforts or best services clauses in their contracts, collective bargaining agreements and league constitutions as well. ${ }^{51}$ The state of Nevada has actually addressed the issue of best efforts in its statutes. Many boxing, mixed martial arts (MMA) and combat sports contests occur in the state, and Nevada law states that the Nevada Commission my suspend, revoke or discipline contestants or participants if in its judgment is "... guilty of a failure to give his best efforts, a failure to compete honestly or a failure to give an honest exhibition of his skills in a contest or exhibition of unarmed combat;. . ."152

The sport of tennis brought the concept of best efforts to the forefront of discussion in recent years. Allegations of corrupt betting and match-fixing in the sport drew attention to the Association of Tennis Professionals (ATP) rules which state that a player's failure to use his or her best efforts or to otherwise artificially influence the outcome of a tennis match undermines these intrinsic values. ${ }^{153}$ In 2007 , Nikolay Davydenko (RUS) was fined $\$ 2,000$ for "lack of best effort" during an event though it was later rescinded. ${ }^{154}$ In 2010, Romanian Victor Hanescu was fined $\$ 15,000$ total for unsportsmanlike conduct and failing to use his "best efforts" at Wimbledon. ${ }^{155}$

College Coaching Contracts Revisited: A Practical Perspective, 12 MARQ. SPORTS L. REV. 127, 151$2(2001)$.

150. Triple-A Baseball Club Assocs., 832 F.2d at 225.

151. See, e.g., Jeffrey Standen, The Beauty of Bets: Wagers as Compensation for Professional Athletes, 42 WILLAMETTE L. REV. 639, 647-649 (2006) (referencing the integrity, loyalty and best services clauses found in MLB and NBA uniform player contracts); see also David C. Weiss, How Terrell Owens, Collective Bargaining, and Forfeiture Restrictions Created a Moral Hazard that Caused the NFL Crime Wave and What It Meant for Michael Vick, 15 SPORTS LAW. J. 279, 312-13 (2008) (noting that each NFL player commits himself to: "give his best efforts and loyalty to the club and to conduct himself on and off the field with appropriate recognition of the fact that the success of professional football depends largely on the public respect for and approval of those associated with the game...); see also Orr v. Nat'l Football League Players' Ass'n, 35 Va. Cir. 156 (Cir. Ct. Virg. 1994).

152. NEV. REV. STAT. ANN. $\$ 467.110(2010)$.

153. See 2011 ATP OFFICIAL RULEBOOK, p.148, available at http:/www.atpworldtour.com/ Corporate/Rulebook.aspx. ("A player shall use his best efforts during the match when competing in a tournament. Violation of this section shall subject a player to a fine up to $\$ 10,000$ for each violation.").

154. See Associated Press, After Reviewing Video, ATP Rescinds Davydenko Fine, ESPN (Nov. 13, 2007), http://sports.espn.go.com/sports/tennis/news/story?id=3107972.

155. See Associated Press, Hanescu Fined for Spitiing in Match, ESPN (June 26, 2010), http://sports.espn.go.com/sports/tennis/wimbledon10/news/story?id=5331093. 


\section{Loyalty Clauses}

Similar to best efforts, a loyalty clause represents a somewhat subjective way to terminate an agreement in the event the employee or endorsee fails to keep his promise to remain loyal to the employer or endorser. ${ }^{156}$ For example, Indiana University's contract with current head coach Tom Crean addresses "loyalty" at the beginning of the contract on the first page of the agreement and actually combines "loyalty" and a "best efforts" clause in the same paragraph. $^{1}$

However, some assert that a loyalty clause is nothing more than an effort by one party to exercise its superior bargaining power or position over the other and demonstrating unconscionability. ${ }^{158}$ In sum, a loyalty clause calls for the employee-endorsee to refrain from failing to wear and use a particular brand of product in public or bad-mouthing the organization publicly. ${ }^{159}$ For example in 2005 Atlanta Falcons cornerback DeAngelo Hall wore Nike shoes during a Monday Night Football game. The problem was that he was endorsed by Reebok. ${ }^{160}$ Similarly, in 2000, Shawn Kemp (NBA) told the Akron Beacon Journal that his favorite pair of shoes was Nike's Air Force II's. He, too, was under contract with Reebok. ${ }^{161}$

\section{E. No Trade Clauses}

Finally, another clause worth exploring is the no-trade clause which allows a player the right to rescind a trade under certain conditions. No-trade clauses demonstrate the nature of the bargaining relationship between a team

156. See Robert H. Lattinville \& Robert A. Boland, Coaching in the National Football League: A Market Survey and Legal Review, 17 MARQ. SPORTS L. REV. 109, 147 (2006);

157. Indiana University Employment Agreement, Aug. 11, 2008. Paragraph 2.01 (A) reads, in part, "I. Loyalty and Best Efforts. The Employee agrees to devote his best efforts and abilities fulltime to the performance of his duties for the exclusive benefit of the University...".

158. See, e.g., Thomas E. Fielder, Keep Your Mouth Shut and Listen: The NFL Player's Right of Free Expression, 10 U. MIAMI BuS. L. REV. 547, 557-560 (2002).

159. Id. at 553-55 (noting that the Cincinnati Bengals football club added an addendum provision to their standard player contracts that would allow the team to take away part of a player's signing bonus after Carl Pickens' sharp criticism of the team management and expressing his desire to be traded, now known in some circles as the "Pickens Clause"); but see Chris Deubert \& Glenn M. Wong, Understanding the Evolution of Signing Bonuses and Guaranteed Money in the National Football League: Preparing for the 2011 Collective Bargaining Negotiations, 16 UCLA ENT. L. REV. $179,225(2009)$ (noting that the Bengals' addendum was upheld by an arbitrator after a grievance was brought by the NFLPA).

160. See Darren Rovell, Reebok Dumps Hall for Wearing Nikes, ESPN (Oct. 26, 2005), http://sports.espn.go.com/nfl/news/story?id=2204711.

161. Id. 
and a player at the time of signing a contract, in particular the concept of leverage in the negotiation process, or in the case of the big four leagues such considerations are instituted in the respective collective bargaining agreements. For example, in the 2005-2011 NHL collective bargaining agreement, there are both no-Trade (NTC) and no-move clauses (NMC). ${ }^{162}$

In many cases, no-trade clauses also limit where a club may be limited to trading the athlete only at certain times, or only to a certain team or geographical area though they are often waived by players in order to play for a championship contending team. 2001, Tampa Bay Devil Rays first baseman Fred McGriff mulled for days over waiving his rights before ultimately accepting a deal which sent him to the Chicago Cubs. ${ }^{163}$ In 2010, Cy Young Award winner Zack Greinke of the Kansas City Royals was traded to the Milwaukee Brewers though his unique no-trade clause, in which he could submit 15 teams that he could block a trade to, demonstrated its power. ${ }^{164}$ Discussion of the no trade clause should provide the student and professor alike pause as to how far sports contracts and particular clauses have come since the days of the reserve system.

\section{VIII.CONCLUSION}

Exploration of various clauses and contracts in the context of sports and the law can provide professors and students with an exciting and comprehensive pedagogical journey. From the 1922 ruling in Federal Baseball, which held that the game was exempt from federal antitrust laws thereby upholding the legitimacy of the reserve clause, to the Curt Flood Act of 1998 and the various challenges and rulings in between; the nature and role of contract clauses in sports remains as important as ever. Challenges to baseball's reserve system helped to shape the American legal landscape and led to the formation of players associations which helped define bargained-for boundaries between owners and players. The role of the Commissioner

162. NATIONAL HOCKEY LEAGUE, supra note 57, at $\$ 11.8$ (“Individually Negotiated Limitations on Player Movement"); see also Matthew Wuest, How Henrik Sedin Can Limit Ducks, CAPGEEK.COM (Nov. 17, 2010), available at http:/insider.espn.go.com/nhl/insider/news/ story? id =5814099 (noting that the basic difference between a NTC and an NMC is that the NMC prevents the NHL team from moving the player to the minors and is granted usually only to franchisecaliber players).

163. See, e.g., Michael A. McCann, It's Not About the Money: the Role of Preferences, Cognitive Biases, and Heuristics Among Professional Athletes, 71 BrookL YN L. REv. 1459, 1500 (2006).

164. See Jeff Passan, Greinke is $O K$ with Pinstripes, YAHOO SPORTs (Nov. 30, 2010), http://sports.yahoo.com/mlb/news?slug=jp-greinkehotstove113010; see also Buster Olney, Sources: Albert Pujols Would Veto Trade, ESPN THE MAGAZINE (Jan. 29, 2011), available at http://sports.espn.go.com/mlb/news/story? id $=6070963$. 
appears to be as important as ever especially with regard to the "best interests" of baseball clause.

The advent of no-trade clauses, freedom clauses, and the right to free agency, has given players more power in the contractual relationship than they have ever had. Still, as demonstrated by loyalty and best efforts clauses, owners, teams and sponsors place personal conduct, loyalty and responsibility on the shoulders of players as never before either. Meanwhile, morals clauses, hazardous activity clauses, and best efforts clauses have gained considerable momentum in importance and interpretation. Others such as the most favored nation and freedom clauses, demonstrate and reflect the creativity and foresight of one or both of the parties to the agreement. An exploration of the role of termination clauses in coaching contracts demonstrates how important it is for the parties to consider the manner in which the coach can be fired and how for "cause" provisions can be defined. It also offers an opportunity to consider why some athletic directors might make perplexing decisions to hire some coaches who appear to have a nomadic employment resume coupled with a history of violations of NCAA rules.

Ultimately, an analysis of clauses in sports would work quite well in an undergraduate or graduate law course. Reviewing sports contracts also allows for a fun consideration of the history of American jurisprudence and the role of courts and precedent in contract drafting and interpretation. It will be interesting to see what new agreements emerge following the expiration of the current collective bargaining agreements among the various professional leagues. A continuous examination of sports contracts and clauses allows for a comprehensive exploration of the role of contract law generally from a larger perspective as well: to provide predictability and stability in among the working relationships among individuals and organizations in society in an effort to enforce the principle that agreements must be served.

\section{ABOUT THE AUTHOR}

ADAM EPSTEIN is Professor in the Department of Finance and Law at Central Michigan University. He has written three textbooks and has published numerous peer-reviewed and journal articles especially in the areas of sports law, contract law, and business law. He can be reached at adam.epstein@cmich.edu.

\section{REFERENCES}

Abrams, R.I. (2007). Blackmun's list. Virginia Sports \& Entertainment Law Journal, 6, 181-207. 
Alesia, M. (2010). IUPUI: Paying Coach Shann Hart $\$ 300,000$ beat being sued. Retrieved March 19, 2011, from http://iphone.indystar.com/posts/39987

Arcella, C.F. (1997). Major League Baseball's disempowered commissioner: Judicial ramifications of the 1994 restructuring. Columbia Law Review, 97, 2420-2469.

Associated Press. (2001). NFL notebook: Gramatica's celebration costs Cardinals. Retrieved March 19, 2011, from http://www.seattlepi.com/ football/51044_nfln18.shtml

Associated Press. (2005). Neuheisel says he feels vindicated by settlement. Retrieved March 19, 2011, from http://sports.espn.go.com/ ncf/news/story?id=2007123

Associated Press. (2006). Sampson barred from off-campus recruiting. Retrieved March 19, 2011, from http://sports.espn.go.com/ncb/news/story?id=2457878

Associated Press. (2007). After reviewing video, ATP rescinds Davydenko fine. Retrieved March 19, 2011, from http://sports.espn.go.com/ sports/tennis/news/story?id $=3107972$

Associated Press. (2007). Louisville files lawsuit claiming breach of contract. Retrieved March 19, 2011, from http://sports.espn.go.com/ncf/ news/story?id=3100938

Associated Press. (2010). Bobby Gonzalez, Seton Hall settle. Retrieved March 19, 2011, from http://sports.espn.go.com/new-york/news/story?id=5471121

Associated Press. (2010). Cam Newton wins Heisman Trophy. Retrieved March 19, 2011, from http://sports.espn.go.com/ncf/news/story?id=5909569

Associated Press. (2010). Hanescu fined for spitting in match. Retrieved March 19, 2011, from http://sports.espn.go.com/sports/tennis/wimbledon10/news/ story?id $=5331093$.

Associated Press. (2011). Asomugha misses incentives; Raiders void 3-year, \$45.3M Deal. Retrieved March 18, 2011 from http:/sportsillustrated.cnn. com/2011/football/nfl/01/09/asomugha.raiders.ap/index.html

Associated Press. (2011). Suns sign guard Dowdell to second 10-day contract. Retrieved March 19, 2011, from http://sportsillustrated.cnn.com/2011/ basketball/nba/01/27/dowdell.suns.ap/index.html

ATP. (2011). 2011 ATP Official Rulebook. Retrieved March 19, 2011, from http://www.atpworldtour.com/Corporate/Rulebook.aspx 
Auman, G. (2011). USF settles ex-coach Jim Leavitt's lawsuit for $\$ 2.75$ Million. Retrieved March 19, 2011, from http://www.tampabay.com/sports/college/ usf-settles-ex-coach-jim-leavitts-lawsuit-for-275-million/1144945

Backman, S.E. (2002). NFL players fight for their freedom: The history of free agency in the NFL. Sports Lawyers Journal, 9, 1-56.

Barker, J. (2010). Tennessee cancels UNC series: Time for Vols to leave SEC or fire AD. Retrieved March 19, 2011, from http://bleacherreport.com/articles/ 438109-tennessee-cancels-unc-series-time-for-vols-to-move-on

Barrington, D. (2010). NFL postpones Vikings-Eagles to Tuesday because of snow. Retrieved March 19, 2011, from http://content.usatoday.com/ communities/thehuddle/post/2010/12/blizzard-pushes-vikings-and-eagles-totuesday-night/1

Bautista, P.R. (2000). Congress says, "Yooou're out!!!" to the antitrust exemption of professional baseball: A discussion of the current state of player-owner collective bargaining and the impact of the Curt Flood Act of 1998. Ohio State Journal on Dispute Resolution, 15, 445-482.

Bernacchio, A. (2011). Johnny Damon and Manny Ramirez sign with the Rays: Reunited and it feels so good. Bleacher Report. Retrieved March 19, 2011, from http://bleacherreport.com/articles/582071-reunited-and-it-feels-sogood-johnny-damon-and-manny-ramirez-sign-with-the-rays

Bohl, J.C. (2008). Generations X and $Y$ in law school: Practical strategies for teaching the "MTV/Google" generation. Loyola Law Review, 54, 775-799.

Boland, R.A. \& Lattinville, R.H. (2006). Coaching in the National Football League: A market survey and legal review. Marquette Sports Law Review, 17, 109-191.

Boston Celtics Ltd. P'ship v. Brian Shaw, 908 F.2d 1041 (1st Cir. 1990).

Bouchard Transp. Co. v. N.Y. Islanders Hockey Club, 836 N.Y.S.2d 654 (App. Div. 2007).

Bridgeman v. Nat'1 Basketball Ass'n, 675 F. Supp. 960 (D.N.J. 1987).

Brown v. Pro-Football, Inc., 518 U.S. 231 (1996).

Cedrone, T.D., Pinguelo, F.M. \& Taylor, P.L. (2010). The reverse-morals clause: The unique way to save talent's reputation and money in a new era of corporate crimes and scandals. Cardozo Arts \& Entertainment Law Journal, $28,65-113$. 
Chapin, T. (2000). The political economy of sports facility location: an end-ofthe-century review and assessment. Marquette Sports Law Journal, 10, 361382.

Clarett v. National Football League, 306 F. Supp. 2d 379 (S.D.N.Y. 2004), rev'd, 369 F.3d 124 (2d Cir. 2004), cert. denied, 125 S. Ct. 1728 (2005).

CNN. (2009). Phelps suspended from competition, dropped by Kellogg. CNN.com. Retrieved March 19, 2011, from http://www.cnn.com/2009/ US/02/05/kellogg.phelps

Cohane v. NCAA, 2007 U.S. App. LEXIS 1841 (2d Cir. 2007), cert. denied, 2007 U.S. LEXIS 12179 (2007).

Cole v. Valley Ice Garden, 113 P.3d 275 (Mont. 2005).

Coman, N. (2010). Chris Coghlan tears meniscus throwing pie as celebrationinduced injury strikes again. Daily Blend. Retrieved March 19, 2011, from http:/www.nesn.com/2010/07/chris-coghlan-tears-meniscus-throwing-pieas-celebrationinduced-injury-strikes-again.html

Curt Flood Act of 1998, 15 U.S.C. § 26b (2011).

DeCock, L. (2010). Letter of intent in college athletics is faulty. Charlotte Observer. Retrieved March 19, 2011, from http://www.charlotteobserver. com/2010/08/08/1608585/letter-of-intent-faulty.html

Denver Rockets v. All-Pro Mgmt., Inc., 325 F. Supp. 1049 (C.D. Cal. 1971).

Deubert, C. \& Wong, G.M. (2009). Understanding the evolution of signing bonuses and guaranteed money in the National Football League: Preparing for the 2011 collective bargaining negotiations. UCLA Entertainment Law Review, 16, 179-236.

Dryer, R.T. (2008). Beyond the box score: A look at collective bargaining agreements in professional sports and their effect on competition. Journal of Dispute Resolution, 2008, 267-292.

Easter, B.A., Hardin, S.E. \& Stenger, T.L. (2003). Legal issues related to adventure racing. Journal of Legal Aspects of Sport, 13(2), 253-263.

Edelman, M. (2003). How to curb professional sports' bargaining power vis-à-vis the American city. Virginia Sports \& Entertainment Law Journal, 2, 280309.

Edelman, M. (2009). Are commissioner suspensions really any different from illegal group boycotts? Analyzing whether the NFL personal conduct policy illegally restrains trade. Catholic University Law Review, 58, 631- 662. 
Edmonds, E. (2010). At the brink of free agency: Creating the foundation for the Messersmith-McNally decision 1968-1975. Southern Illinois University Law Journal, 34, 565-619.

Ellis, M. (2010). Bruce Pearl era at Tennessee might be coming to an end. Bleacher Report. Retrieved March 19, 2011, from http://bleacherreport. $\mathrm{com} /$ articles/550645-bruce-pearl-era-at-tennessee-may-be-drawing-near-tothe-end

Epstein, T. (2005). Splinters from the bench: Feasibility of lawsuits by athletes against coaches and schools for lack of playing time. Virginia Sports \& Entertainment Law Journal, 4, 174-197.

ESPN.com News Services. (2008). Indiana, Sampson reach $\$ 750,000$ settlement to part ways. ESPN.com. Retrieved March 19, 2011, from http://sports.espn.go.com/ncb/news/story?id=3258506

ESPN.com News Services. (2009). Mangino out at Kansas. ESPN.com. Retrieved March 19, 2011, from http://sports.espn.go.com/ ncf/news/story?id=4711389

ESPN.com News Services. (2010). Giants-Vikings moved to Ford Field. ESPN.com. Retrieved March 19, 2011, from http://sports.espn.go.com/ $\mathrm{nfl} /$ news/story? $\mathrm{id}=5911532$

ESPN.com News Services. (2010). SEC suspends Pearl 8 games. ESPN.com. Retrieved March 19, 2011, from http://sports.espn.go.com/ncb/news/ story?id $=5824966$

ESPN.com News Services. (2011). ESPN.com. Mike Leach plans to appeal. Retrieved March 19, 2011, from http://sports.espn.go.com/ncf/ news/story?id $=6044702$

ESPN.com News Services. (2010). Tom Fenton found, signed by Coyotes. ESPN.com. Retrieved March 19, 2011, from http://sports.espn.go.com/ nhl/news/story?id $=5927810$

Federal Baseball Club of Baltimore, Inc. v. Nat'l League of Professional Baseball Clubs, 259 U.S. 200 (1922).

Fielder, T.E. (2002). Keep your mouth shut and listen: The NFL player's right of free expression. University of Miami Business Law Review, 19, 547-583.

Fitzgerald, D. (2009). A more detailed look at Marist v. Brady. Connecticut Sports Law. Retrieved March 19, 2011, from http://ctsportslaw.com/2009/08/ 06/a-more-detailed-look-at-marist-v-brady/

Flood v. Kuhn, 407 U.S. 258 (1972). 
Foote, M.A. (2009). Three strikes and you're (not necessarily) out: How baseball's erratic approach to conduct violations is not in the best interest of the game. DePaul Journal of Sports Law \& Contemporary Problems, 6, 139.

Garcia, M. (2010). Ex-coach Jimmy Collins shows no sympathy for Bruce Pearl. USA Today. Retrieved March 19, 2011, from http://www.usatoday.com/ sports/college/mensbasketball/2010-09-12-jimmy-collins-bruce-pearl_N.htm

Gardella v. Chandler, 172 F.2d 402 (2d Cir. 1949).

Gasper, C.L. (2007). Virtually perfect. Retrieved March, 19, 2011, from http:/www.boston.com/sports/football/patriots/articles/2007/07/20/virtually perfect/

Gillerman, J.D. (2010). Calling their shots: Miffed minor leaguers, the steroid scandal, and examining the use of Section 1 of the Sherman Act to hold MLB accountable. Albany Law Review, 73, 541-573.

Greenberg, M.J. (2001). College coaching contracts revisited: A practical perspective. Marquette Sports Law Review, 12, 127-260.

Greenberg, M.J. (2006). Termination of college coaching contracts: When does adequate cause to terminate exist and who determines its existence? Marquette Sports Law Review, 17, 197-257.

Griffith, M. (2010). UT terminated Pearl's contract but working on new one. Go Vols Xtra. Retrieved March 19, 2011, from http://www.govolsxtra.com/ news/2010/oct/21/ut-terminated-pearls-contract-working-new-one/

Grow, N. (2010). Defining the "business of baseball": A proposed framework for determining the scope of professional baseball's antitrust exemption. $U C$ Davis Law Review, 44, 557-623.

Haywood v. Nat'l Basketball Ass'n, 401 U.S. 1204 (1971).

Heisman Trophy. (2011). Heisman trust mission statement. Retrieved March 19, 2011, from http://www.heisman.com/trust/mission_statement.php

Hyland, R. (1994). Pacta sunt servanda: A meditation. Virginia Journal of International Law, 34, 405-433.

Int'l Boxing Club v. U.S., 358 U.S. 242 (1955).

Javier, R.A. (2009). "You cannot choke your boss \& hold your job unless you play in the NBA": The Latrell Sprewell incident undermines disciplinary authority in the NBA. Villanova Sports \& Entertainment Law Journal, 7, 209-236. 
Jones, J.P. (1999). A congressional swing and miss: The Curt Flood Act, player control, and the national pastime. Georgia Law Review, 33, 639-691.

Kaiser, L.L. (2004). Revisiting the impact of the Curt Flood Act of 1998 on the bargaining relationship between players and management in Major League Baseball. DePaul Journal of Sports Law and Contemporary Problems, 2, 230-263.

Kaplan, R.A. (2004). The NBA luxury tax model: A misguided regulatory regime. Columbia Law Review, 104, 1615-1650.

Karcher, R.T. (2009). The coaching carousel in big-time intercollegiate athletics: Economic implications and legal considerations. Fordham Intellectual Property, Media \& Entertainment Law Journal, 20, 1-93.

Katz, A. (2010). Bruce Pearl protected by contract. ESPN.com. Retrieved March 19, 2011, from http://sports.espn.go.com/ncb/news/story?id=5582439

Keveney, B. (2008). Injury forces May-Treanor to sit out this 'Dancing.' USA Today. Retrieved March 19, 2011, from http://www.usatoday.com/life/ television/news/2008-10-06-may-treanor-injury_N.htm

Lowe, Z. (2010). The Texas Rangers sale: A test case for the power of sports leagues? Retrieved March 19, 2011, from http://www.law.com/jsp/tal/ PubArticleTAL.jsp?id=1202458105113\&The_Texas_Rangers_Sale_A Test Case_for_the_Power_of_Sports_Leagues\&hbxlogin $=1$

Mackey v. NFL, 543 F.2d 606 (8th Cir. 1976).

Maddox v. Univ. of Tenn., 62 F.3d 843 (6th Cir. 1995).

Major League Baseball. (2007). Collective bargaining agreement.

Major League Constitution ("MLC") (2005). Retrieved March 19, 2011, from http://bizofbaseball.com/docs/MLConsititutionJune2005Update.pdf

McCann, M.A. (2006). It's not about the money: The role of preferences, cognitive biases, and heuristics among professional athletes. Brooklyn Law Review, 71, 1459-1528.

McMann, A. (2010). Vague Language in football contract with IU may not bring results. Central Michigan Life. Retrieved March 19, 2011, from http://www.cm-life.com/2010/07/14/vague-language-in-football-contractwith-iu-may-not-bring-results/

Moberg, B.C. (2006). Navigating the public relations minefield: Mutual protection through mandatory arbitration clauses in college coaching contracts. Journal of Legal Aspects of Sport, 16, 85-115.

Nader v. ABC Television, Inc., 150 Fed. Appx. 54 (2d Cir. 2005). 
Nathanson, M. (2005). The irrelevance of baseball's antitrust exemption: A historical review. Rutgers Law Review, 1, 12-43.

National Basketball Association (July 2005). Collective bargaining agreement.

National Football League (2006). Collective bargaining agreement.

National Hockey League (2005). Collective bargaining agreement.

NBA v. Williams, 45 F.3d 684 (2d Cir. 1995).

Nev. Rev. Stat. Ann. $\S 467.110$ (2011).

Nike Int'l, Ltd. v. Athletic Sales, Inc., 689 F. Supp. 1235 (D.P.R. 1988).

Nomura, J.Y. (2009). Refereeing the recruiting game: Applying contract law to make the intercollegiate recruitment process fair. University of Hawaii Law Review, 32, 275-304.

O’Brien v. Ohio State Univ., 2007 Ohio 4833 (Ct. App. 2007).

O'Connor, I. (2010). Hey Bud, don't shrug this one off. ESPN.com. Retrieved March 19, 2011, from http:/sports.espn.go.com/new-york/mlb/ columns/story?columnist $=$ oconnor ian\&id $=5245642$.

Olney, B. (2011). Sources: Albert Pujols would veto trade. ESPN The Magazine. Retrieved March 19, 2011, from http://sports.espn.go.com $/ \mathrm{mlb} /$ news/ story?id=6070963

O'Neil, D. (2009). Gillispie, Kentucky part ways. ESPN.com. Retrieved March 19, 2011, from http://sports.espn.go.com/ncb/news/story?id=4021232

Orr v. Nat'l Football League Players' Ass'n, 35 Va. Cir. 156 (1994).

Otto, K.A. \& Stippich, K.S. (2010). Carrying a good joke too far? An analysis of the enforceability of student-athlete consent to use of name \& likeness. Journal of Legal Aspects of Sport, 20(2), 151-184.

Parlow, M.J. (2010). Professional sports league commissioners' authority and collective bargaining. Texas Review of Entertainment \& Sports Law, 11, 179-203.

Passan, J. (2010). Greinke is OK with pinstripes. Retrieved March 19, 2011, from http://sports.yahoo.com/mlb/news?slug=jp-greinkehotstove113010

Philadelphia World Hockey Club, Inc., v. Philadelphia Hockey Club, Inc., 351 F. Supp. 457 (E.D. Pa. 1972).

Primm, A. (2010). Salary arbitration induced settlement in Major League Baseball: The new trend. Sports Lawyers Journal, 17, 73-115.

Radovich v. Nat'1 Football League, 352 U.S. 445 (1957). 
Robertson v. Nat'l Basketball Ass'n, 389 F. Supp. 867 (S.D.N.Y. 1975).

Rodgers v. Georgia Tech Athletic Ass'n, 303 S.E.2d 467 (Ga. Ct. App. 1983).

Roe, B. (2002). Predators report: The two-way contract dilemma. Retrieved March 19, 2011, from http://www.hockeysfuture.com/articles/4553/ predators_report the twoway contract_dilemma/

Rovell, D. (2005). Reebok dumps Hall for wearing Nikes. Retrieved March 19, 2011, from http://sports.espn.go.com/nfl/news/story?id=2204711

Rushdi, F. (2009). The Washington Senators played a part in baseball's free agent history. Retrieved March 18, 2011, from http://bleacherreport.com/articles/277211-the-washington-senators-played-apart-in-baseballs-free-agent-history

Sandomir, R. (2010). Selig widens 'best interests' view in Rangers bid. New York Times. Retrieved March 19, 2011, from http://www.nytimes.com/ 2010/05/15/sports/15sandomir.html

Sirotkin, D. (2009). Disciplining the disciplinary systems in professional sports: An attempt to fix the arbitrary and overreaching disciplinary powers of sports commissioners. Cardozo Journal of Conflict Resolution, 11, 289-317.

Snyder, M. (2007, July 11). U-M partners with Adidas. Detroit Free-Press, Sports p. 2.

Spencer, L. (2010). Kendry's walk-off slam comes with injury. Retrieved March 19, 2011, from http://mlb.mlb.com/news/article.jsp?ymd=20100529\& content_id $=10569596 \&$ vkey $=$ recap\&fext $=. j s p \& c \_i d=m l b$

Standen, J. (2006). The beauty of bets: Wagers as compensation for professional athletes. Willamette Law Review, 42, 639-668.

State v. Milwaukee Braves, Inc. 144 N.W.2d 1 (Wis. 1966).

Stevens, A. (2011). Damon Evans ex-UGA athletic director pleads guilty to DUI charge. Atlanta Journal Constitution. Retrieved March 19, 2011, from http://www.ajc.com/news/damon-evans-ex-uga-816707.html

Stiglitz, J. (1995). Player discipline in team sports. Marquette Sports Law Journal, 5, 167-188.

Sulentic, K. (2009). Running backs, recruiting, and remedies: College football coaches, recruits, and the torts of negligent and fraudulent misrepresentation. Roger Williams University Law Review, 14, 127-162.

Swartz, K.E. (2011). Lawsuit: Thrashers owners have been trying to sell team since 2005. Atlanta Journal Constitution. Retrieved March 19, 2011, from 
http://www.ajc.com/sports/lawsuit-thrashers-owners-have-811606.html? cxtype $=$ rss_news

Tomlinson, M.M. (2008). The commissioner's new clothes: The myth of Major League Baseball's antitrust exemption. St. Thomas Law Review, 20, 255-310.

Toolson v. New York Yankees, 346 U.S. 356 (1953).

Triple-A Baseball Club Assocs. v. Northeastern Baseball, Inc., 832 F.2d 214 (1st Cir. 1987).

U.S. v. Int'l Boxing Club of New York, 348 U.S. 236 (1955).

United States Football League v. Nat'1 Football League, 842 F.2d 1335 (2d Cir. 1988).

Univ. of Louisville v. Duke Univ., No. 07-CI-1765 (Franklin Cir. Ct. June 19, 2008).

Van Breda Kolff v. St. Bonaventure Univ., (CV 04-03270) (W.D.N.Y. 2003).

Vanderbilt Univ. v. DiNardo, 174 F.3d 751 (6th Cir. 1999).

Walker, J. (2009). Sources: Smith has weight clause. ESPN.com. Retrieved March 19, 2011, from http://sports.espn.go.com/nfl/trainingcamp09/ news/story?id $=4437525$

Way, G.D. (1997). Sudden death: League labor disputes, sports licensing and force majeure neglect. Marquette Sports Law Journal, 7, 427-463.

Weir, T. (2010). Cam Newton left off at least 6 Heisman ballots. USA Today. Retrieved March 19, 2011, from http:/content.usatoday.com/communities/ gameon/post/2010/12/cam-newton-heisman-trophy-ballots/1

Weiss, D.C. (2008). How Terrell Owens, collective bargaining, and forfeiture restrictions created a moral hazard that caused the NFL crime wave and what it meant for Michael Vick. Sports Lawyers Journal, 15, 279-325.

Wood v. Nat'1 Basketball Ass'n, 809 F.2d 954 (2d Cir. 1987).

Wuest, M. (2010). How Henrik Sedin can limit Ducks. ESPN.com. Retrieved March 19, 2011, from http://insider.espn.go.com/nhl/insider/ news/story?id $=5814099$ 